\title{
Sanksi Ekonomi dalam Tinjauan Politik dan Diplomasi Internasional: Resensi Buku
}

\author{
Achmad Ismail \\ Universitas Indonesia
}

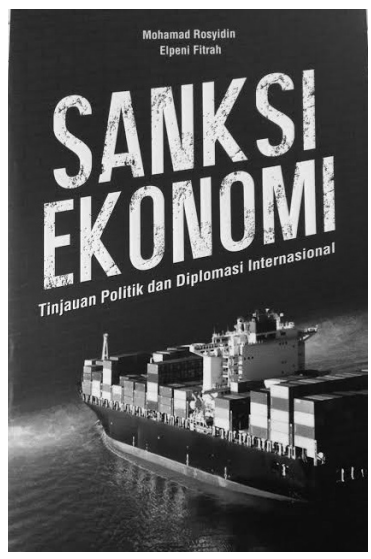

Judul Buku

Penulis

Penerbit

Tahun terbit

ISBN

Jumlah halaman
: Sanksi Ekonomi Tinjauan Politik dan Diplomasi Internasional

: Mohamad Rosyidin \& Elpeni

Fitrah

: Pustaka Ilmu Group

: 2016

: 978-602-6835-18-5

: $262+$ xiv

Setiap negara memiliki tujuan politik luar negeri yang berbedabeda. Tentunya hal ini tidak lepas dari adanya motivasi untuk memenuhi kepentingan nasional mereka. Dalam upaya untuk mencapai tujuan politik luar negeri tersebut, ada beberapa opsional yang dapat digunakan oleh negara, semisal penerapan sanksi ekonomi. Beberapa negara memandang bahwa sanksi ekonomi sebagai bentuk diplomasi koersif atau juga disebut sebagai alternatif perang. Secara definisi, para pakar ilmu HI memiliki satu suara yang disarikan oleh penulis buku ini bahwa sanksi ekonomi adalah kebijakan penghukuman negara lain disebabkan karena ketidaksesuaian antara tindakan yang dilakukan satu negara dengan harapan dari negara lain dan atau komunitas internasional (Rosyidin \& Fitrah, 2016).

Beberapa negara terbilang sukses dalam menerapkan sanksi ekonomi terhadap suatu negara. Hal itu dibuktikan dengan mempengaruhi kebijakan negara penerima sanksi (target) mengikuti tujuan negara pengirim (sender) yang telah ditentukan. Namun tak jarang juga beberapa negara terbilang gagal dalam menerapkanya. Oleh karenanya, bukan perkara mudah dalam penerapan sanksi ekonomi yang dilakukan oleh suatu negara sebagai sebuah hukuman. Adanya alternatif negara lain yang membantu, dampaknya yang meluas ke masyarakat, tidak tepat sasaran dan sebagainya menjadi sebuah paradoks dalam penerapan sanksi ekonomi.

Poin-poin inilah yang diulas secara mendalam oleh Mohamad Rosyidin serta Elpeni Fitrah dalam buku mereka yang berjudul Sanksi Ekonomi: Tinjauan Politik dan Diplomasi Internasional. Buku ini sangat menarik 
bagi para akademisi Hubungan Internasional. Buku ini mengisi beberapa kekosongan buku ilmiah sekaligus ibarat oase bagi para akademisi HI yang berkonsentrasi dengan bahasan diplomasi koersif melalui sanksi ekonomi. Kekosongan pertama ialah pasalnya buku ini merupakan buku pertama yang mengulas tentang sanksi ekonomi dengan literatur berbahasa Indonesia, dimana pada umumnya, telah banyak diulas dalam literatur Bahasa asing (Inggris). Kekosongan kedua yang diisi oleh buku ini yaitu beberapa buku ilmiah HI dengan literatur Bahasa Indonesia lebih berfokus pada tataran sebuah pengantar. Kekosongan terakhir yang menjadi fokusnya adalah umumnya dengan kata 'sanksi ekonomi' lebih berfokus pada kajian ilmu ekonomi yang bersifat kuantitatif. Sehingga buku ini mengisi tiga kekosongan yang ada yaitu buku yang mengulas tentang sanksi ekonomi dengan berbahasa Indonesia dengan fokus disiplin ilmu HI.

Mohamad Rosyidin dan Elpeni Fitrah mengemas bahasan sanksi ekonomi ke dalam buku ini sangat komprehensif, terstruktur dan sistematis. Hal tersebut tersurat dari komposisi buku yang disusun. Para penulis membaginya kedalam dua bagian utama. Bagian pertama, para penulis berfokus menjabarkan tentang sanksi ekonomi dalam tataran perspektif teoritis dan bagian kedua, memberikan fokus bahasannya pada beberapa studi kasus penerapan sanksi ekonomi. Inilah yang membuat para pembaca buku ini menjadi lebih paham terkait sanksi ekonomi. Pemahaman ini tercuat karena tidak hanya sekedar dibahas pada tataran teoritis, juga menjadi lebih paham pada beberapa studi kasus secara faktual. Pembabakan seperti ini memberikan pemahaman lebih jelas kepada para akademisi HI memandang sanksi ekonomi ke dalam beberapa perspektif $\mathrm{HI}$, oleh karenanya menjadi penjelas sekaligus pembeda bagaimana beberapa perspektif $\mathrm{HI}$ memandang satu fenomena yaitu sanksi ekonomi. Hadirnya beberapa contoh kasus dalam bab buku ini mengindikasikan pula kekuatannya, dengan kata lain, pembaca dihadapkan langsung ke dalam penerapan perspektif HI, keberhasilan/kegagalan serta dilema yang dihadapi dalam penerapan sanksi ekonomi.

Pada bagian pembuka, buku ini memaparkan secara detil mengenai sejarah penerapan sanksi ekonomi. Bermula pada zaman Yunani Kuno, ada sebuah dekrit yaitu Dekrit Megarian dikeluarkan oleh Pericles yang dipicu menjadi penyebab perang antara Athena dan Sparta. Dekrit ini melarang aktivitas perdagangan orang-orang Megaria di wilayah Athena, hal inilah yang disangkakan sebagai tindakan perang. Penerapan sanksi ekonomi masih terus berlanjut hingga masa abad pertengahan, Perang Dunia I dan II hingga pasca Perang Dingin usai. Menariknya pada bahasan ini seakan-akan penerapan sanksi ekonomi terhadap negara lain (target) dijadikan sebagai alat untuk mengalahkan pihak lawan. Pada masa tersebut seringkali terjadi perang secara militer, namun untuk mengalahkan lawan, sender tidak bisa mengandalkan instrumen militer saja namun juga mengandalkan dari penerapan sanksi ekonomi.

Buku ini sangat relevan bagi akademisi $\mathrm{HI}$, pasalnya dalam buku ini menganalisis cara pandang dari tiga perspektif utama HI terhadap 
penerapan sanksi ekonomi, yaitu realisme, liberalisme serta konstruktivisme. Pertama, realisme identik dengan sifat dari sistem internasional yang anarchy \& self-help. Oleh karenanya realisme memandang bahwa penerapan sanksi ekonomi merupakan bentuk dari suatu negara untuk mencapai kepentingannya sendiri/menolong dirinya sendiri di tengah kondisi anarki. Cara pandang lain yang hadir ialah sanksi ekonomi digunakan untuk memamerkan power (kekuasaan) atau bargaining position yang dimiliki dalam konstelasi politik internasional, terlebih ingin melemahkan negara lawan. Hal ini penting sebagai sinyal bahwa jangan 'bermain-main' dengan negara sender sekaligus menjadi ajang pembuktian harga diri, kapabilitas yang dimiliki melebihi negara lainnya.

Kedua, perspektif liberalisme lebih menitikberatkan bahwa penerapan sanksi ekonomi sebagai akumulasi dari aspirasi interest group domestik suatu negara. Hal ini dikarenakan pada liberalisme yang identik dengan non-state actor memiliki pengaruh yang besar, sementara state actor hanya dianggap sebagai perpanjangan tangan saja. Walhasil, non-state actor lah yang merumuskan kepentingan nasionalnya melalui sanksi ekonomi. Cara pandang yang menarik lainnya ketika sanksi ekonomi diterapkan dengan tujuan kepentingan non-materil. Dalam artian bahwa negara sender menjatuhkan sanksi ekonomi terhadap negara target dengan maksud lain menyebarkan nilai-nilai liberalisme itu sendiri, semisal penegakan HAM, demokrasi, free trade terlebih sebagai containment terhadap paham komunis/ otoriter.

Terakhir adalah konstruktivisme. Perspektif ini berasumsi bahwa segala sesuatu yang terjadi dalam politik internasional bukan sebuah hal yang bersifat given, melainkan terlahir dari sebuah gagasan (ideas), dimana hal ini terbentuk atas identitas serta kepentingan aktor. Melihat asumsi tersebut, maka konstruktivisme memandang penerapan sanksi ekonomi lebih dipengaruhi oleh identitas/karakteristik dari negara sender itu sendiri, dengan kata lain identitas/gagasan itulah yang menjadi dominan atas tindakan yang akan dilakukan. Cara pandang lainnya adalah bahwa penerapan sanksi ekonomi sebagai tindakan yang tidak bersumber dari aktor secara murni, namun lebih didominasi akibat karena adanya struktur/ norma internasional yang membentuk aktor untuk menerapkan sanksi ekonomi selain karena sudah diatur/legal.

Salah satu bab pada buku ini menghadirkan analisa mendalam beberapa perdebatan empirik yang menarik semisal tujuan dari penerapan sanksi ekonomi serta perdebatan menarik lainnya manakala sanksi ekonomi dapat dikatakan sukses atau gagal. Secara formalitas penerapan sanksi ekonomi bertujuan sebagai tindakan penghukuman terhadap negara target yang melakukan pelanggaran agar mereka menyadari dan tidak terulang kembali pelanggaran tersebut. Namun apakah negara sender dengan serta merta memberikan sanksi ekonomi sebagai tindakan hukuman secara simbolik semata?. Secara kontemporer, tujuan itu sudah mulai bergeser dan hanya bersifat formalitas saja. Hal ini terjadi ketika beberapa kasus, negara sender menerapkan sanksi ekonomi berniat untuk intervensi 
terhadap proses pembuatan keputusan di negara target tanpa harus menggunakan armada militer. Dengan kata lain, tindakan ini dianggap sebagai bagian dari upaya intervensi terhadap perubahan kebijakan negara target. Maka buku ini memandang dua hal tersebut tidak dalam suatu hal yang bertolak belakang, maka negara sender hampir tidak mungkin hanya memberikan sanksi simbolik sebagai hukuman tanpa ada niatan intervensi merubah kebijakan negara target, mengingat bahwa cost yang dikeluarkan/ ditanggung tidaklah sedikit.

Dalam buku ini pula menghadirkan perdebatan terkait efektivitas berhasil atau tidaknya penerapan sanksi ekonomi. Sebagaimana Holsti (1977) mengatakan bahwa ada beberapa kasus sanksi ekonomi berhasil sebagai kebijakan luar negeri untuk mencapai kepentingan nasionalnya serta ada yang tidak berhasil. Beberapa pihak merasa optimis terhadap penerapan sanksi ekonomi berhasil, namun dengan beberapa catatan penting. Pertama, menentukan perbandingan besar kecilnya biaya yang ditanggung oleh negara sender dan negara target. Logika sederhananya, biaya yang ditanggung oleh negara target harus lebih besar dari biaya yang diterima oleh negara sender. Kedua, perlunya dukungan dari aktor-aktor lain. Ketika banyak aktor yang bersepakat menjatuhkan sanksi ekonomi kepada negara target, maka kondisinya semakin tertekan untuk menghadapi sanksi ekonomi tersebut. Hal ini tidak mudah, karena penyamaan persepsi penerapan sanksi ekonomi dengan aktor lain membutuhkan waktu untuk proses bargaining.

Ketiga, besaran faktor ketergantungan. Negara target akan lebih mudah 'mengalah' atas sanksi ekonomi yang diterimanya dengan pertimbangan bahwa mereka masih memiliki ketergantungan terhadap negara sender. Keempat, bersifat multisektor serta multiaktor. Dalam kondisi demikian, negara target semakin terhimpit atas sanksi ekonomi yang diberikan serta dampak yang terjadi dikemudian hari semakin berdampak meluas. Kelima, mempertimbangkan karakter rezim politik dari negara target. Sanksi ekonomi besar kemungkinan berhasil bila ditujukan kepada negara sekutu dan demokratis, pasalnya negara sekutu (target) memiliki ketergantungan tinggi terhadap negara sender serta minim akan resistensi serta beberapa faktor lain yang turut serta mempengaruhi sanksi ekonomi menjadi berhasil.

Perdebatan muncul dari pihak yang merasa pesimis terhadap penerapan sanksi ekonomi. Kegagalan penerapan sanksi ekonomi dikarenakan oleh beberapa faktor, pertama, cost besar yang dikeluarkan oleh negara sender tidak diperoleh secara maksimal. Ini menjadi hal mendasar ketika negara sender melalui sanksi ekonomi dengan biaya besar, harus diimbangi dengan tercapainya kepentingan nasionalnya atau mendapatkan cost lebih dari yang dikeluarkan. Kedua, kemampuan beradaptasi negara target. Ketika negara target mampu mencari pengganti (subtitusi) dari apa yang dikenakan dalam sanksi ekonominya, maka sudah dipastikan sanksi ekonomi tersebut tidak berjalan efektif sehingga negara target terlepas dari tekanan sanksi ekonomi. Ketiga, tidak adanya otoritas 
tertinggi di atas negara. Hal ini tidak lepas dari sistem internasional yang bersifat anarki, maka dari itu negara berhak melakukan apapun sesuai kedaulatan mereka. Tidak ada satupun yang berhak melarang, menyuruh negara berdaulat sehingga tidak ada sistem yang mengawasi aktivitas negara oleh dunia internasional. Keempat, sanksi ekonomi tidak efektif bila dikenakan terhadap negara otoriter. Hal ini disebabkan karena negara tersebut akan melakukan resistensi terhadap sanksi ekonomi terlebih menggalang kekuatan (nasionalisme) untuk mencari cara agar sanksi ekonomi yang dikenakan tidak berdampak meluas.

Dibalik penerapan sanksi ekonomi ada beberapa permasalahan yang menarik untuk ditelisik yaitu melanggar prinsip moralitas (HAM). Disatu sisi penerapan sanksi ekonomi ditujukan untuk menghukum negara yang melakukan pelanggaran, terutama pelanggaran HAM, namun di sisi lain, penerapan sanksi ekonomi secara "brutal" menjadi penyebab pelanggaran prinsip HAM lanjutannya. Paradoks sanksi ekonomi ini diperparah ketika melihat realitas, paska dijatuhi sanksi ekonomi, kondisi di negara target terjadi kelaparan, kemiskinan, pengangguran, hilangnya akses pendidikan hingga kematian. Negara sender acapkali menerapkan sanksi ekonomi secara "brutal" dalam artian kata menyentuh ke berbagai sektor dan aktor di negara target. Kondisi demikian membuat dunia internasional berfokus pula pada kerugian moralitas yang diderita oleh masyarakat sipil. Merespon hal tersebut, muncullah kajian human security yang berfokus pada penegakan hukum dan HAM, perlindungan terhadap masyarakat sipil dalam kondisi konflik serta pembangunan berkelanjutan di berbagai sektor.

Perdebatan semakin mencuat dikala penerapan sanksi ekonomi menyentuh ke berbagai sektor (sanksi komprehensif) pun berlangsung dalam jangka waktu lama. Maka yang dirugikan tidak hanya menghancurkan ekonomi, juga seluruh tatanan masyarakat sebagai akibat dampak sanksi ekonomi. Di lain pihak berpandangan hal tersebut tidak lantas membuat eksistensi sanksi ekonomi lantas ditiadakan, karena sanksi ekonomi ini bertujuan sebagai tindakan penghukuman sekaligus alternatif perang terbuka. Tidak adanya titik temu dari perdebatan di atas, membuat buku ini menawarkan sebuah konsep smart sanction atau targeted sanction (Hakimdavar, 2014), sebagai jalan tengahnya. Konsep ini masih belum menjawab secara penuh perdebatan di atas, namun konsep inilah yang saat ini dikedepankan.

Secara sederhana konsep smart sanction adalah model sanksi ekonomi yang dialamatkan kepada elit politik/militer negara target sekaligus meminimalisir dampak negatifnya kepada masyarakat sipil (Rosyidin \& Fitrah, 2016). Dikarenakan smart sanction ditujukan kepada individu, maka bentuk sanksi nya pun untuk individu semisal travel ban, embargo militer, pembekuan asset di luar negeri, pembatasan pembelian barang dan sebagainya. Hingga saat ini, konsep smart sanction cukup sering diterapkan, pasalnya sanksi ekonomi yang dijatuhkan benar-benar ditujukan kepada individu terkait, sehinngga tidak berdampak pada masyarakat sipil. Namun 
pihak lainnya berpandangan pula bahwa meskipun ditujukan kepada satu individu, ada dampak lainnya yang akan dirasakan oleh masyarakat sipil (spill-over effect) tak jarang juga negara sender kerapkali tidak tepat menentukan individu yang akan dijatuhi sanksi.

Kesimpulannya, buku ini menjadi literatur penting bagi penstudi ilmu HI, khususnya yang berkonsentrasi pada kajian ekonomi politik internasional. Pasalnya buku ini berhasil memberikan analisa mendalam tentang kajian sanksi ekonomi yang dikupas melalui kacamata ilmu HI. Hal itu ditandai dengan konsep sanksi ekonomi diulas menggunakan tiga perspektif utama dalam ilmu HI. Kedua penulis pula berhasil menjabarkan paradoks nyata yang dihadapi oleh negara terkait penerapan sanksiekonomi, dimana penerapan ini bertujuan sebagai tindakan penghukuman agar negara target mematuhinya, namun bersamaan dengan hal itu dampaknya terasa meluas bahkan pada pelanggaran prinsip-prinsip moralitas masyarakat sipil. Kemudian, keduanya berhasil menjawab paradoks saat ini dengan menelaah smart sanction yang kerapkali digunakan oleh banyak negara. Tidak hanya itu, buku ini membuat pembacanya akan paham secara menyeluruh karena pada empat bab terakhir disertakan beberapa studi kasus negara yang berhasil dan gagal menerapkan sanksi ekonomi, negara yang menggunakan sanksi ekonomi sebagai alat diplomasi serta sebagai alternatif perang.

\section{Daftar Pustaka}

Hakimdavar, G. (2014) A Strategic Understanding of UN Economic Sanctions: International Relations, Law and Development. London: Routledge.

Holsti, K. J. (1977) International Politics: A Framework Analysis. New Jersey: Prentince-hall.

Rosyidin, M. \& Fitrah, E. (2016) Sanksi Ekonomi: Tinjauan Politik dan Diplomasi Internasional. Yogyakarta: Pustaka Ilmu Group. 